Januari Kristining Tyas, Apolonia Antonilda Ina, Probo Tjondronegoro

Pengaruh Terapi Akupresur Titik Sanyinjiao Terhadap Skala Dismenore

\title{
Pengaruh Terapi Akupresur Titik Sanyinjiao Terhadap Skala Dismenore
}

\author{
Januari Kristining Tyas ${ }^{1}$, Apolonia Antonilda Ina ${ }^{2}$, Probo Tjondronegoro ${ }^{3}$ \\ 1) \\ Program studi S1 Ilmu Keperawatan STIKES St. Elisabeth Semarang \\ Dosen STIKES St. Elisabeth Semarang
}

Korespondensi penulis: nininkina@yahoo.com

\begin{abstract}
Abstrak
Masa pubertas adalah salah satu tahap perkembangan yang ditandai dengan kematangan organ seksual dan tercapainya kemampuan untuk bereproduksi, dimana salah satu ciri dari tanda pubertas seorang perempuan yaitu dengan terjadinya menstruasi pertama (menarche). Dimana saat remaja mengalami menstruasi tidak sedikit remaja merasakan nyeri haid atau dismenore. Berbagai cara dapat mengurangi dismenore saat menstruasi, salah satunya dengan terapi akupresur titik Sanyinjiao. Penelitian ini bertujuan untuk membuktikan adanya pengaruh terapi akupresur titik Sanyinjiao terhadap skala dismenore pada remaja putri. Penelitian ini menggunakan desain deskriptif analitik dengan pendekatan Cross Sectional. Populasi yang digunakan adalah siswi SMA Mardisiswa Semarang sebanyak 80 sampel, diambil dengan teknik Purposive Sampling. Pengukuran skala dismenore dilakukan dua kali yaitu sebelum dan sesudah perlakuan terapi akupresur titik Sanyinjiao dengan menggunakan lembar observasi. Uji statistik menggunakan Wilcoxon. Hasil uji statistik didapatkan hasil $p<0.001$ yang berarti ada pengaruh terapi akupresur titik Sanyinjiao terhadap skala dismenore $(p<0.005)$.
\end{abstract}

Kata kunci: dismenore; terapi akupresur titik Sanyinjiao

\section{PENDAHULUAN}

Masa remaja merupakan suatu masa peralihan dari pubertas ke dewasa atau suatu proses tumbuh ke arah kematangan yang mencakup kematangan mental, emosional, sosial, dan fisik. Masa pubertas adalah salah satu tahap perkembangan yang ditandai dengan kematangan organ seksual dan tercapainya kemampuan untuk bereproduksi, dimana salah satu ciri dari tanda pubertas seorang perempuan yaitu dengan terjadinya menstruasi pertama (menarche) (Janiwarty \& Pieter, 2017).

Menarche merupakan pertanda bahwa seorang remaja mengalami pubertas, pada masa pubertas kadar lutainizing hormone (LH) dan follicel stimulating hormone (FSH) akan meningkat sehingga merangsang pembentukan hormon seksual. Peningkatan hormon tersebut menyebabkan beberapa perubahan fisik pada remaja putri seperti siklus menstruasi (Andira, 2013). Hari pertama keluarnya darah menstruasi ditetapkan sebagai hari pertama siklus endometrium. Usia menarche terjadi antara umur 10 sampai 16 tahun. Cepat atau lambatnya menarche tergantung pada faktor genetik, gizi dan faktor fisiologis dari remaja (Andriyani, 2015). Menstruasi atau haid adalah perdarahan secara periodik dan siklik dari uterus, disertai pelepasan (deskuamasi) endometrium (Lestari, 2013). Menstruasi terjadi karena sel telur yang dikeluarkan oleh salah satu ovarium tidak mengalami pembuahan. Menstruasi biasanya dimulai antara usia 
Januari Kristining Tyas, Apolonia Antonilda Ina, Probo Tjondronegoro

Pengaruh Terapi Akupresur Titik Sanyinjiao Terhadap Skala Dismenore

10 sampai 16 tahundan pada kenyataannya banyak wanita yang mengalami masalah menstruasi, diantaranya nyeri haid atau dismenore (Murtiningsih, 2015).

Dismenore adalah keluhan ginekologis akibat ketidakseimbangan hormon progesteron dalam darah sehingga mengakibatkan timbul rasa nyeri yang paling sering terjadi pada wanita (Murtiningsih, 2015). Dismenore bukanlah suatu penyakit, melainkan gejala yang timbul akibat adanya kelainan dalam rongga panggul dan mengganggu aktifitas perempuan, bahkan sering kali berdampak pada remaja usia sekolah karena menyebabkan terganggunya aktivitas sehari-hari. Seorang siswi yang mengalami dismenore tidak dapat berkonsentrasi belajar dan motivasi belajar akan menurun karena dismenore yang dirasakan pada saat proses belajar mengajar. Dismenore pada remaja harus dapat ditangani dengan tindakan yang tepat untuk menghindari dampak negatif yang akan timbul (Efriyanthi, 2015).

Dismenore primer dialami oleh 60$75 \%$ wanita muda. Pada $75 \%$ wanita yang mengalaminya intensitas kram ringan atau sedang, sedangkan pada $25 \%$ nyerinya berat dan membuat penderita tidak berdaya. Dismenore primer biasanya terjadi pada perempuan muda nulipara dengan pemeriksaan pelvis normal (Wirawan et al, 2011). Dismenore sekunder lebih jarang ditemukan dan terjadi pada $25 \%$ wanita yang mengalami dismenore dan penyebabnya adalah endometritis, fibroid, adenomiosis, peradangan tuba fallopi, perlekatan abnormal antzara organ diperut dan pemakaian IUD(Intra Uterin Device) (Ernawati, 2010). Perempuan semakin tua, lebih sering mengalami menstruasi maka leher rahim bertambah lebar, sehingga pada usia tua kejadian dismenore jarang ditemukan. Menarche pada usia lebih awal (< 12 tahun) menyebabkan alat-alat reproduksi belum berfungsi secara optimal dan belum siap mengalami perubahanperubahan sehingga timbul nyeri ketika menstruasi (Sherwood, 2014).

Angka kejadian nyeri menstruasi di dunia sangat besar.Rata-rata lebih dari $50 \%$ perempuan disetiap negara mengalami nyeri menstruasi. Menurut World Health Organization (WHO) tahun 2012 angka presentasenya sekitar $60 \%$. Secara global pada tahun 2015, usia menarche bervariasi antara 9-18 tahun dengan usia rata- rata di Amerika Serikat menjadi sekitar 13 tahun, sementara di Asia, telah dilaporkan sekitar 12 tahun (Murtiningsih, 2015). Angka kejadian dismenore tahun 2011 di Indonesia sebesar $64,25 \%$ yang terdiri dari $54,89 \%$ diemenore primer dan 9,36\% dismenore sekunder. Provinsi Jawa Tengah tahun 2013 angka kejadian dismenore sebesar $56 \%$. Survey yang dilakukan pada siswi di kota Semarang ditemukan kejadian dismenore ringan sebanyak $18 \%$, dismenore sedang $62 \%$ dan dismenore berat 20\% (Novia, 2008). Hal ini akan dapat mengganggu aktifitas dan kegiatan belajar sehingga akan dapat mengganggu prestasi belajar mahasiswa. Hal ini dibuktikan dalam suatu penelitian, dimana $71 \%$ dari 100 wanita usia 15 - 30 tahun yang mengalami dismenore, 5,6\% diantaranya tidak dapat masuk sekolah atau tidak dapat bekerja, serta ditemukan 59,2\% mengalami kemunduran produktifitas kerja yang diakibatkan oleh dismenore (Widjanarko, 2006).

Ada beberapa cara yang dapat dilakukan untuk mengatasi nyeri secara non farmakologis antara lain terapi akupresur titik Sanyinjiao yaitusalah satu akupoin atau titik pertemuan limpa, hati dan saluran ginjal yang terletak di limpa meridian, yaitu empat jari di atas dalam pergelangan kaki belakang tepi posterior tibia (Hasanah, 2014). Terapi akupresur dapat meningkatkan hormon endorphin pada otak yang secara alami dapat membantu menawarkan rasa nyeri. Penelitian Efriyanthi (2015) tentang Pengaruh Terapi Akupresur titik 
Sanyinjiao terhadap Intensitas Nyeri

Dismenore Primer Pada Mahasiswi Semester VIII Program Studi IlmuKeperawatan, menunjukkan bahwa terdapat perubahan yang signifikan antara skala nyeri dismenore pre test dan post test pada kelompok perlakuan dengan nilai Asymp. Sig. (2-tailed) sebesar $0.000 \quad(\mathrm{p}<0,05)$. Penelitian Hasanah (2014) tentang efektifitas terapi akupresur terhadap intensitas nyeri saat dismenore pada remaja di SMPN 5 dan SMPN 13 Pekanbaru menunjukkan bahwa terjadi penurunan intensitas nyeri yang signifikan setelah akupresur ( $p$ - value<0,05) (Judha, 2012).

Berdasarkan hasil studi pendahuluan pada 8 Mei 2017 di SMA Mardisiswa Semarang, didapatkan hasil bahwa 100 dari 108 siswi remaja putri mengalami dismenore saat menstruasi, sehingga angka prevalensi dari studi pendahuluan tersebut adalah sebesar 93\%. Selain itu dari studi pendahuluan juga melihat beberapa remaja hanya memilih berdiam diri, tidur, tidak melakukan aktivitas dan meminum obat ataupun jamu saat nyeri menstruasi. Berdasarkan hasil studi pendahuluan dan penelitian sebelumnya maka peneliti tertarik untuk melakukan penelitian ini dengan judul "PengaruhTerapi Akupresur Titik Sanyinjiao Terhadap Skala Dismenore".

\section{METODE}

Jenis penelitian ini menggunakan kuantitatif deskriptif analitik dengan jenis hipotesis komparatif yang dilakukan secara pre-experimental design dengan metode yang digunakan adalah "one group pre-post test design". Penelitian ini menggunakan pendekatan cross sectional yang dilakukan pada satu waktu untuk mencari pengaruh antara variabel bebas dengan variabel terikat dengan melakukan pengukuran skala nyeri sebelum dan sesudah perlakuan (Dahlan, 2011). Populasi adalah keseluruhan subjek yang akan diteliti. Populasi penelitian ini adalah siswi SMA Mardisiswa Semarang yang mengalami dismenore sebanyak 100 orang.

Cara pengambilan sampel dengan menggunakan metode purposive sampling, yaitu pengambilan sampel dengan karakteristik populasi yang sudah ditentukan. Sampel ditetapkan berdasarkan kriteria inklusi dan eksklusi.Kriteria inklusi adalah kriteria dimana subjek penelitian mewakili sampel penelitian yang memiliki syarat sebagai sampel. Kriteria eksklusi merupakan kriteria dimana subjek penelitian tidak dapat dijadikan sebagai sampel (Nursalam, 2013).

\section{HASIL PENELITIAN \\ Distribusi Frekuensi Skala Nyeri Dismenore Pretest dan Posttest}

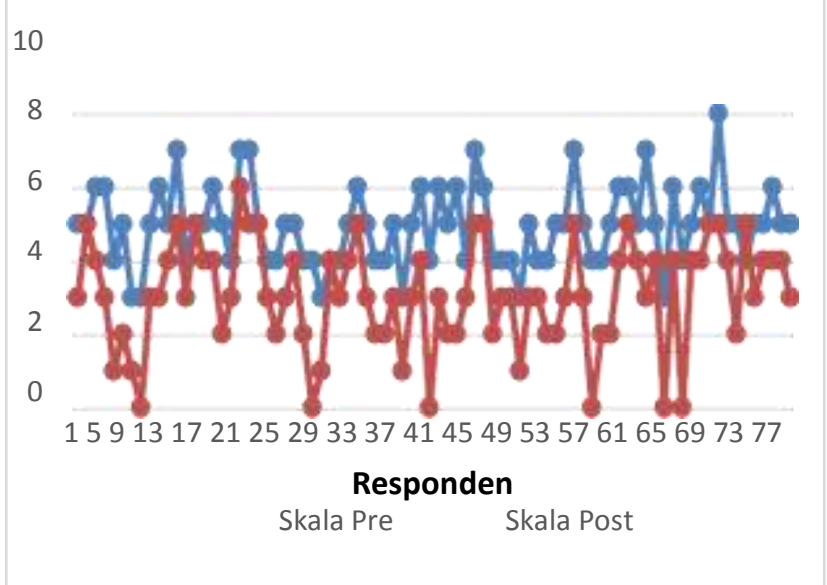

\section{Gambar 1. Frekuensi Skala Nyeri Dismenore Pretest dan Post Test $(\mathbf{n}=\mathbf{8 0})$}

Berdasarkan grafik di atas terjadi perubahan sebelum dan sesudah perlakuan terapi akupresur titik Sanyinjiao selama 10 menit pada masing-masing kaki. Skala sebelum perlakuan tertinggi 1 orang dengan skala nyeri berat yaitu skala nyeri 8 dan 
Januari Kristining Tyas, Apolonia Antonilda Ina, Probo Tjondronegoro

Pengaruh Terapi Akupresur Titik Sanyinjiao Terhadap Skala Dismenore

skala sesudah perlakuan terendah adalah tidak ada nyeri dismenore atau skala 0 (6 orang).

\section{PEMBAHASAN}

Berdasarkan dari hasil observasi 3 jam setelah perlakuan didapatkan terdapat penurunan skala nyeri, dimana penelitian yang dilakukan pada siswi SMA Mardisiswa Semarang menghasilkan bahwa terapi akupresur titik Sanyinjiao dapat menurunkan skala dismenore. Skala dismenore pada 80 responden sebelum dilakukan terapi akupresur paling banyak pada skala sedang (skala 4-6) yaitu skala 5.

Endorphin adalah pembunuh rasa nyeri yang dihasilkan sendiri oleh tubuh. Endorphin merupakan molekul- molekul peptida atau protein yang dibuat dari zat yang disebut beta- lipoptropin yang ditemukan pada kelenjar pituitary. Selain itu endorphin dapat mempengaruhi daerah-daerah pengindra nyeri di otak dengan cara yang serupa dengan obat-obat opiate seperti morfin. Pelepasan endorphin dikontrol oleh sistem saraf, saraf sensitif dengan rangsangan nyeri dari luar dan begitu dipicu dengan menggunakan teknik akupresur, akan menginstruksikan sistem endokrin untuk melepas sejumlah endorphin sesuai kebutuhan tubuh (Wulandari, 2011).

Saat mengalami nyeri haid atau dismenore lalu dilakukan pemijatan akupresur titik Sanyinjiao tubuh akan merangsang saraf untuk melepaskan hormon endorphin. Berdasarkan prinsipprinsip Pengobatan Tradisional Cina (TCM), akupresur pada titik Sanyinjiao berfungsi untuk memperkuat limpa, mengembalikan keseimbangan Yin pada hati dan ginjal, sehingga hal tersebut dapat memperkuat pasokan darah dan memperlancar peredaran darah, dengan demikian akupresur pada titik sanyinjiao dapat mengurangi nyeri dismenore (Hadiyanto, 2006).

Pada penelitian Hadiyanto (2006) ditemukan ada beberapa responden yang tidak mengalami perubahan sebanyak 4 orang dengan nilai skala dismenore seperti dengan skala sebelumnya, ditemukan juga 1 orang yang mengalami peningkatan skala nyeri dari skala 4 menjadi skala 5. Dari hasil penelitian ini terdapat responden yang tidak mengalami perubahan dan mengalami peningkatan skala nyeri dapat dipengaruhi oleh faktor yang tidak dapat dikontrol oleh peneliti, yaitu faktor hormonal dari masing-masing responden, kepercayaan responden terhadap pemijatan akupresur sendiri dan juga stres yang dialami oleh responden. Setelah dilakukan pemijatan pada saat jam istirahat sekolah dan hanya beristirahat sebentar kemudian responden harus kembali dalam kegiatan belajar mengajar yang dapat mempengaruhi tingkat stres pada responden.

Faktor psikologis yang dialami remaja putri SMA Mardisiswa Semarang ini juga disebabkan salah satunya adalah tugas yang dimiliki oleh siswi di sekolah, seperti banyak pekerjaan rumah yang harus diselesaikan dalam waktu dekat, atau tugas- tugas dari guru lainnya. Hal ini sedikit atau banyak kemungkinan akan menimbulkan stres. Stres merupakan gangguan pada tubuh dan pikiran yang disebabkan oleh perubahan dan tuntutan kehidupan yang dipengaruhi baik oleh lingkungan ataupun penampilan individu didalam lingkungan tersebut. Lingkungan dan kehadiran orang disekitar juga dapat mempengaruhi nyeri responden, lingkungan yang kurang tenang atau terlalu bising membuat responden merasa semakin tidak nyaman saat mengalami nyeri haid. Seseorang yang memfokuskan perhatiannya terhadap nyeri akan 
Januari Kristining Tyas, Apolonia Antonilda Ina, Probo Tjondronegoro

Pengaruh Terapi Akupresur Titik Sanyinjiao Terhadap Skala Dismenore

mempengaruhi persepsinya terhadap nyeri itu sendiri (Potter \& Perry, 2009).

Berdasarkan hasil penelitian yang telah dilakukan dapat disimpulkan bahwa terapi akupresur titik Sanyinjiao dapat menurunkan skala dismenore. Hasil dari uji beda yang dilakukan dengan uji alternatif Wilcoxon didapatkan nilai $\mathrm{p}<0.01$. Hasil penurunan skala dismenore dari penelitian sebelum dan sesudah dilakukan terapi akrupresur pada titik Sanyinjiao menunjukkan bahwa terapi akupresur dapat digunakan sebagai pengurang rasa nyeri haid atau dismenore.

\section{KESIMPULAN}

Skala dismenore sebelum diberikan terapi akupresur titik Sanyinjiao memperoleh hasil nilai median 5.00. Skala dismenore sesudah diberikan terapi akupresur titik Sanyinjiao memperoleh hasil nilai median 3.00.

Berdasarkan uji hipotesa Wilcoxon didapatkan hasil $\mathrm{p}<0.001$ yang berarti H1 diterima yaitu ada pengaruh terapi akupresur titik Sanyinjiao terhadap penurunan skala dismenore pada siswi SMA Mardisiswa Semarang.

\section{DAFTAR PUSTAKA}

Andira, D. (2013). Seluk Beluk Kesehatan Reproduksi Wanita. Yogyakarta: Arruzz Media.

Andriyani, Rika. (2015). Buku Ajar Biologi Reproduksi Dan Perkembangan. Yogyakarta: Depublish.

Dahlan, Sopiyudin. (2011). Statistik Untuk Kedokteran Dan Kesehatan. Jakarta: Salemba Medika.

Efriyanthi, IGAA Sri., Suardana, I Wayan., Suari, Wayan. (2015). Pengaruh Terapi Akupresur Sanyinjiao Point terhadap
Intensitas Nyeri Dismenore Primer pada Mahasiswa Semester VIII Program Studi Ilmu Keperawatan. Coping Ners Journal, vol. 3, no. 2. ISSN: 23031298.

Ernawati. (2010). Terapi Relaksasi terhadap Nyeri Dismenore pada Mahasiswi Universitas Muhammadiyah Semarang. Seminar nasional Unimus. Available from http://download.portalgaruda.org/ article.php?article $=4294$ \&val $=426$.

Hadiyanto, Joko Suyono. (2006). Fundamental Of Obstetrics And Gynaecology. Jakarta: Hipokrates.

Hasanah, Oswati. (2014). Efektifitas Terapi Akupresur Terhadap Dismenore pada Remaja di SMAN 5 dan SMN 13 Pekanbaru. Jurnal Universitas Indonesia.

Janiwarty, \& Pieter, H. Z. (2017). Pendidikan Psikologi Untuk Bidan Suatu Teori Dan Terapannya. Yogyakarta: Rapha Publishing.

Judha, Mohamad., Sudarti., Afroh, F. (2012). Teori Pengukuran Nyeri Dan Nyeri Persalinan. Yogyakarta: Nuha Medika.

Lestari, Ni Made Sri Dewi. (2013). Pengaruh Dismenorea Pada Remaja. Seminar Nasional FMIPA Undiksha Iii [Home Page On The Internet]. C2013 [Update 2013 September 06; Cited On 2017 Desember 20]. Available from http://Ejournal.Undiksha.Ac.Id/In dex.Php/Semnasmipa/Article/V iew/2725.

Murtiningsih, $M$ \& Karlina, Lina. (2015). Penurunan Nyeri Dismenore Primer Melalui Kompres Hangat Pada Remaja. Jurnal Keperawatan Padjajaran, vol. 3 , no. 2 . 
Januari Kristining Tyas, Apolonia Antonilda Ina, Probo Tjondronegoro

Pengaruh Terapi Akupresur Titik Sanyinjiao Terhadap Skala Dismenore

Nursalam. (2013). Metode Penelitiam Ilmu Keperawatan Pendekatan Praktis. Edisi 3. Jakarta: Salemba Medika.

Novia, L. (2008). Faktor Resiko yang Mempengaruhi Kejadian Dismenore Primer. Available from http://www.journal.unair.ac.id/fi lerPDF/Naskah\%204\%20(h96103).pdf.

Potter \& Perry. (2009). Fundamental of Nursing, edisi 7. Jakarta: Salemba Medika.

Widjanarko, Bambang. (2006). Dismenore Tinjauan Terapi pada Dismenore Primer. Makalah Kedokteran Damianus, volume. 5, no. 1 .

Wirawan, J.P., Prasmusinto, D. (2011). The Unique Presentation of Massive Ascites Complicating Severe Preeclampsia and HELLP Syndrome. Indonesian Journal of Obstetrics and Gynecology. Available from http://www.nmcth.edu/im ages/gallery/Case\%20Report/JO NjpP\%20pradhan.pdf.

Wulandari, R. (2011). Hubungan aktivitas olah raga dan Obesitas dengan kejadian syndrome premenstruasi di desa Pucangmiliran Tulung Klaten. Jurnal Stikes Aisyiyah.

Sherwood, L. (2014). Fisiologi Manusia. Edisi 8. Jakarta: EGC. 